\title{
ANALISIS POLA PIKIR (MINDSET), PENILAIAN KERJA DAN KEPEMIMPINAN TERHADAP KINERJA PEGAWAI PADA KANTOR KECAMATAN BATUMANDI KABUPATEN BALANGAN KALIMANTAN SELATAN
}

\author{
Ermina Suriyanti* \\ Sekolah Tinggi Ilmu Ekonomi Pancasetia \\ Jl. Ahmad Yani Km. 5.5 Banjarmasin \\ ermina.suriyanti@yahoo.co.id
}

\begin{abstract}
Abstrak : Ermina Suriyanti, Npm. 1811.32202.4733, Analisis Pola Pikir (Mindset), Penilaian Kerja Dan Kepemimpinan Terhadap Kinerja Pegawai Pada Kantor Kecamatan Batu Mandi Kabupaten Balangan Kalimantan Selatan, Dibawah Bimbingan Rosadiro Cahyono Dan Yudi Rahman, 2020. Tujuan yang ingin dicapai dalam penelitian ini adalah untuk mengetahui dan menganalisis pengaruh pola pikir (mindset), penilaian kerja dan pola kepemimpinan secara parsial terhadap kinerja ASN, untuk mengetahui dan menganalisis pengaruh pola pikir (mindset), penilaian kerja dan pola kepemimpinan secara simultan terhadap kinerja ASN dan untuk mengetahui diantara variabel pola pikir (mindset), penilaian kerja dan pola kepemimpinan yang berpengaruh dominan terhadap kinerja ASN Pada Kantor Kecamatan Batu Mandi Kabupaten Balangan. Populasi dan sampel dalam penelitian ini adalah pegawai kecamatan yang berjumlah 31 orang responden. Teknik pengolahan data yang digunakan adalah metode kuantitatif dengan aplikasi SPSS analisis regresi berganda. Pengujian hipotesis pertama diketahui bahwa pola pikir (mindset), penilaian kerja dan pola kepemimpinan secara parsial terhadap kinerja ASN. Pengujian hipotesis kedua diketahui pula bahwa variabel pola pikir (mindset), penilaian kerja dan pola kepemimpinan secara simultan terhadap kinerja ASN Pada Kantor Kecamatan Batu Mandi Kabupaten Balangan dan pada pengujian hipotesis ketiga diketahui variabel pola pikir (mindset) yang berpengaruh dominan terhadap kinerja ASN Pada Kantor Kecamatan Batu Mandi Kabupaten Balangan
\end{abstract}

\section{Kata Kunci : Pola Pikir (Mindset), Penilaian Kerja, Kepemimpinan dan Kinerja}

Abstrct : Ermina Suriyanti, Npm. 1811.32202.4733, Analysis Of Mindset Patterns, Assessment Of Work And Leadership On Performance In Office Of Batu Mandi District Balangan, Kalimantan Selatan, Bod Guidance Of Rosadiro Cahyono And Yudi Rahman, 2020. The aim of this research is to find out and analyze the influence of mindset, job evaluation and leadership patterns partially on ASN performance, to know and analyze the influence of mindset, work assessment and leadership patterns simultaneously on performance ASN and to find out among the mindset variables, work assessment and leadership patterns that have a dominant influence on ASN performance at the Batu Mandi District Office in Balangan Regency. The population and sample in this study were 31 sub-district employees. The data processing technique used is a quantitative method with the application of SPSS multiple regression analysis. The first hypothesis testing is known that the mindset, work appraisal and leadership pattern partially on the ASN performance. The second hypothesis testing is also known that the mindset variable, work assessment and leadership pattern simultaneously on the ASN performance in Batu Mandi District Office Balangan District and in the third hypothesis testing the mindset variable that has a dominant influence on ASN performance at the Office Batu Mandi District of Balangan Regency.

Keywords : Mindset, Work Assessment, Leadership and The performance 


\section{PENDAHULUAN}

\subsection{Latar Belakang Masalah}

Pada hakekatnya pola pikir ASN erat kaitannya dengan kepuasan (job satisfaction), sehingga dalam hal ini tidak cukup dengan menggunakan kesejahteraan, tetapi juga pendekatan lainnya seperti penilaian kerja. Dessler (1997) menyatakan bahwa penilaian kinerja adalah memberikan umpan balik kepada karyawan dengan tujuan memotivasi orang/pegawai untuk menghilangkan/miminimalkan

kemerosotan kinerja/ berkinerja lebih tinggi lagi. Selain itu menurut Gomes (2000:11) penilaian kinerja (performance appraisal) adalah proses evaluasi seberapa baik pegawai mengerjakan pekerjaan mereka ketika dibandingkan dengan satu set standar, dan kemudian mengkomunikasikannya dengan para pegawai. Penilaian demikian ini juga disebut sebagai penilaian pegawai, evaluasi pegawai, tinjauan kinerja, evaluasi kinerja dan penilaian hasil. Salah satu kegunaan mengukur kinerja untuk tujuan memberikan penghargaan atau dengan kata lain untuk membuat keputusan administratif mengenai si pegawai.

Dalam organisasi pemimpin tidak dapat bekerja sendiri, pemimpin harus dibantu oleh bawahan-bawahannya atau yang biasa disebut dengan pegawai-pegawainya. Guna aktivitas kerja tersebut pegawai-pegawai tersebut harus juga mempunyai kompetensi yang baik dalam bekerja, karena tanpa adanya kompetens yang baik, maka setiap pekerjaan yang ada didalam organsiasi/ instansi tidak akan dapat berjalan dengan baik, yang akhirnya pekerjaan akan kurang maksimal dijalankan dan arahan serta perintah dari pimpinan dalam suatu pekerjaan tidak dapat dikerjakan secara baik, sehingga kinerja dari pegawai ini akan menjadi rendah dan tidak bermanfaat. Berdasarkan penjelasan tersebut di lingkungan Kantor Kecamatan Batu Mandi Kabupaten Balangan juga mengharapkan untuk para pegawainya dapat bekerja secara baik sesuia dengan fungsi dan tugasnya, sehingga kinerjanya dapat mencapai tujuan yang diharapkan, namun semua itu tidaklah mudah dalam menjalankannya, bila dilihat dari permasalahan yang ada selama ini dari aspek pola pikir (mindset) dirasakan masih terkesan sebagian pegawai masih mempunyai pola pikir / cara pandang dari bekerja untuk uang, semata-mata untuk uang, tidak ada pandangan lain hal ini tercermin dalam memberikan pelayanan masih terdapat pegawai yang meminta pembayaran atas jasa pelayanan tidak sesuai atau tidak berdasarkan peraturan, aspek ini kerap kali membawa dampak yang kurang baik terhadap kinerja pegawai lain yang tidak sejalan dengan hal tersebut yang akhirnya dari permasalahan tersebut dapat menghambat kinerja para pegawai maupun instansi. Bila dilihat dari aspek penilaian kerja diketahui selama ini kinerja pegawai Kantor Kecamatan Batu Mandi Kabupaten Balangan masih belum optimal hal ini terlihat dari hasil-hasil kerja yang diinginkan tidak sesuai dengan harapan, kerap kali terjadi adanya miskomunikasi antar pegawai dalam bekerja dan kerap kali kegiatan administratif belum tersusun dengan baik, aspek penilaian yang sering terjadi pada Kantor Kecamatan Batu Mandi Kabupaten Balangan adalah sebagian pegawai masih terlihat bekerja pegawai dalam bekerja membuang-buang waktu saat jam kerja dan seringnya pekerjaan terlambat/tidak sesuai dengan jadwal yang ditentukan serta pegawai kurang optimal dalam melaksanakan tugas seperti terlambat masuk kerja dan pulang kerja lebih awal dari waktu yang ditentukan hal ini tentu saja dapat mengakibatkan pekerjaan menjadi tidak efektif dan efisien. Selain bila dilihat dari aspek kepemimpinan yang ada di dalam instansi Kecamatan Batu Mandi Kabupaten Balangan dikatahui belum optimal, karena selama ini fungsi pemimpin dalam memimpin bawahannya, masih terlihat belum tegas dalam menindak adanya kesalahan yang dilakukan oleh pegawai yang akhirnya kerap kali berdampak terhadap aktivitas kerja instansi. Sehubungan dengan permasalahan tersebut dan guna memberikan gambaran terhadap beberapa faktor yang dapat mempengaruhi kinerja pegawai, maka dalam hal ini penulis berusaha mengadakan penelitian sehubungan untuk membuka wacana 
terhadap peningkatan kinerja pegawai dengan mengangkat permasalahan tersebut kedalam sebuah penelitian dengan tema judul Pengaruh Pola Pikir (Mindset), Penilaian Kerja dan Pola Kepemimpinan Terhadap Kinerja ASN Pada Kantor Kecamatan Batu Mandi Kabupaten Balangan.

\subsection{Rumusan Masalah}

Terkait dengan uraian dari latar belakang tersebut, maka adapun yang menjadi perumusan masalah dalam peneltian ini, yaitu :

1. Apakah pola pikir (mindset), penilaian kerja dan pola kepemimpinan berpengaruh signifikan secara parsial terhadap kinerja ASN Pada Kantor Kecamatan Batu Mandi Kabupaten Balangan?

2. Apakah pola pikir (mindset), penilaian kerja dan pola kepemimpinan berpengaruh signifikan secara simultan terhadap kinerja ASN Pada Kantor Kecamatan Batu Mandi Kabupaten Balangan?

3. Manakah diantara variabel pola pikir (mindset), penilaian kerja dan pola kepemimpinan yang berpengaruh dominan terhadap kinerja ASN Pada Kantor Kecamatan Batu Mandi Kabupaten Balangan?

\section{BAB II}

\section{TINJAUAN PUSTAKA}

\subsection{Landasan Teori}

\subsubsection{Pola Pikir (Mindset)}

Mindset adalah posisi atau pandangan mental seseorang yang mempengaruhi pendekatan orang tersebut dalam menghadapi suatu fenomena. Mindset terdiri dari seperangkat asumsi, metode, atau catatan yang dimiliki oleh seseorang atau kelompok yang tertanam dengan sangat kuat. Menurut Mulyadi (2007:71), mindset merupakan sikap mental mapan yang di bentuk melalui pendidikan, pengalaman dan prasangka. Pola pikir (mindset) adalah cara menilai dan memberikan kesimpulan terhadap sesuatu berdasarkan sudut pandang tertentu atau bentuk pikiran atau carakita berpikir terhadap sesuatu. Harotno (2010:243) Yoga (2008:98) menjelaskan pola pikir (mindset) adalah sekumpulan kepercayaan atau cara berpikir yang mempengaruhi perialku dan sikap seseorang yang akhirnya akan menentukan level keberhasilan hidupnya. Khodijah (2006:117) menjelaskan pola pikir (mindset) adalah satu keaktifan pribadi manusia yang mengakibatkan penemuan yang terarah kepada suatu tujuan dengan pola berpikir untuk menemukan pemahaman/pengertian yang dikehendaki. Budiman (2011:107) menjelaskan pola pikir (mindset) adalah sekumpulan kepercayaan atau cara berpikir yang mempengaruhi perilaku dan sikap seseorang yang akhirnya menentukan level keberhasilan dan masa depan seseorang.

Setyono ( 2006:90) menjelaskan pola pikir manusia pada dasarnya dibedakan menjadi, yakni sebagai berikut:

1) Pola Pikir Tetap ( fixed mindset ) yang menghasilkan kemampuan tetap ( fixed ability )

2) Pola pikir yang Berkembang (growth mindset) yang menghasilkan kemampuan yang berkembang ( changeable ability ).

Pola Pikir yang berkembang merupakan mindset yang positif, yang akan menghasilkan kemampuan yang terus berkembang. Dalam hal ini seperti komputer, mindset positif dapat di install sedangkan mindset negatif dapat di delete atau dihapus. Proses ini dapat dilakukan melalui terapi yang dapat diajarkan kepada siapapun melalui training atau Diklat.

Setyono (2006:92) dalam Kurikulum perubahan Mindset, ada beberapa tehnik untuk melakukan proses perubahan pola pikir, antara lain :

1) NLP (Neuro Linguistic Programming) yaitu suatu cara untuk menyaring berbagai pengalaman atau hal-hal yang dihadapi dalam kehidupan kita seharihari melalui 5 Indera yaitu Penglihatan (visual), Pendengaran ( auditori ), Pencecap rasa ( gustatori), Penciuman ( oflaktori ) dan Perasa sentuhan ( kinesketik ). Program NLP pada dasarnya merupakan proses menggunakan seluruh indera kita untuk berkomunikasi secara alami baik verbal maupun non-verbal baik dengan diri 
sendiri maupun orang lain untuk meraih sukses dalam kehidupan.

2) Kontemplasi yaitu dengan cara mengenali tujuan tentang konsep diri manusia, melakukan kontemplasi, mengevaluasi diri, mengenali sifat baik dan sifat buruk diri, bersihkan hati (qolbu), membuang sifat negatif, komitmen pada sifat positif dan terus menerus melakukan perbaikan. Cara ini juga diterapkan oleh Ary Ginanjar Agustiar dalam ESQ training.

3) Konsep diri (self concept) yaitu semua persepsi kita terhadap aspek diri kita yang meliputi aspek fisik, aspek sosial, dan aspek psikologis yang terbentuk karena pengalaman masa lalu kita dan interaksi kita dengan orang lain. Adapun indikator konsep diri sebagai PNS diarahkan untuk memahami bekerja sebagai ibadah, melakukan budaya kerja efektif, menghindari sikap tidak terpuji, melakukan pelayanan dan pengayoman kepada masyarakat sesuai peraturan yang berlaku dan selalu terus meningkatkan kompetensi diri dengan belajar terus menerus.

4) Pemetaan pikiran (mind map) adalah metode untuk membuat catatan untuk berfikir, peta pemikiran juga digunakan untuk memecahkan masalah, untuk mengingat (menghafal), dan melakukan sesuatu pada saat kita sedang berfikir, atau sewaktu pikiran memasuki otak kita. Pemetaan pikiran akan membuka kreativitas, memperkuat ingatan dan mengubah kehidupan. Mind Map adalah alternatif pemikiran keseluruhan otak terhadap pemikiran linear yang menggapai ke segala arah dan menangkap berbagai pikiran dari segala sudut.

5) Hipnotis, adalah seni komunikasi untuk mempengaruhi seseorang sehingga mengubah tingkat kesadarannya, dicapai dengan cara menurunkan gelombang otak. Hipnosis tidak bisa langsung mengubah perilaku negatif seseorang, tetapi berfungsi membongkar mental block dan mengkondisikan agar seseorang dapat lebih fokus dan kondusif dalam mengubah perilakunya.
Mindset terdiri dari tiga komponen pokok

(Carol S Dweck, 2006), yaitu:

a. Paradigma adalah cara yang digunakan oleh seseorang di dalam memandang sesuatu.

b. Keyakinan Dasar adalah kepercayaan yang dilekatkan oleh seseorang terhadap sesuatu. Jika kita mengerjakan sesuatu yang kita yakini, kita akan mengerjakan sepenuh hati.

c. Nilai Dasar adalah sikap, sifat, dan karakter yang dijunjung tinggi oleh seseorang, sehingga berdasarkan tersebut nilai-nilai tersebut seseorang dibatasi. Nilai atau value adalah kepercayaan atau keyakinan yang di praktekan dalam bentuk tingkah laku oleh orang dalam kehidupan sehari-hari.

Carol Dweck (2006) menyatakan bahwa terdapat dua macam Mindset, yaitu:

1) Fixed Mindset (Mindset Tetap) Mindset tetap (Fixed mindset) ini didasarkan pada kepercayaan bahwa kualitaskualitas seseorang sudah ditetapkan. Jika seseorang memiliki sejumlah inteligensi tertentu, kepribadian tertentu, dan karakter moral tertentu.

2) Growth Mindset (Mindset Berkembang) Mindset berkembang (growth mindset) ini didasarkan pada kepercayaan bahwa kualitas-kualitas dasar seseorang adalah halhal yang dapat diolah melalui upayaupaya tertentu. Meskipun manusia mungkin berbeda dalam segala hal, dalam bakat dan kemampuan awal, minat, atau temperamen setiap orang dapat berubah dan berkembang melalui perlakuan dan pengalaman.

Hakim (2011:95) menjelaskan pola pikir seseorang berbeda-beda, namun pola pikir tersebut bisa diubah dari waktu-kewaktu. Mengubah pola pikir yang ada pada diri kita tidaklah mudah, kita dapat mengubah pola pikir kita dengan cara mempengaruhi komponen pembentuk pola pikir yaitu pengetahuan dan pengalaman.

Menurut Dweck (2012:221) menjelaskan pola pikir dipengaruhi oleh dua faktor, yaitu:

1) Faktor internal

Faktor ini adalah faktor yang ada di diri atau individu seseorang, Pola pikir seseorang 
dapat berubah ketika ia mampu mengubah cara pandangnya terhadap intelegensiyang dimilikinya, baik berdasarkan pengalaman dalam bekerja, keterampilan yang dimiliki dalam bekerja, pengetahuan yang baik dalam bekerja, tingkat pendidikan yang dimiliki. Intinya terkait faktor internal ini perubahan pola pikir yang diusahakan oleh individu sendiri.

2) Faktor eksternal

Faktor ini adalah faktor yang ada di luar diri / individu seseorang atau disekitar individu tersebut, seperti orang tua, saudara, pasangan, rekan kerja, atasan maupun lingkungan sosial, yang intinya dari faktor eksternal ini adalah perubahan pola pikir yang timbul dari pihak luar individu seorang pegawai.

\subsubsection{Penilaian Kerja}

Menurut Hasibuan (2000:87) menjelaskan tentang penilaian kerja adalah kegiatan untuk mengevaluasi perilaku dari prestasi kerja pegawai serta menetapkan kebijaksanaan selanjutnya. Menurut Gomes (2000:11) penilaian kinerja (performance appraisal) adalah proses evaluasi seberapa baik pegawai mengerjakan pekerjaan mereka ketika dibandingkan dengan satu set standar, dan kemudian mengkomunikasikannya dengan para pegawai. Penilaian demikian ini juga disebut sebagai penilaian pegawai, evaluasi pegawai, tinjauan kinerja, evaluasi kinerja dan penilaian hasil. Riset menujukan penggunaan penilaian kinerja yang luas untuk mengadminitrasikan honor dan gaji, memberikan umpan baik kinerja dan mengidentifikasikan kekuatan dan kelemahan pegawai. Budiono (2010:66) penilaiain kerja kadang-kadang merupakan kegiatan manajer yang paling tidak disukai, dan mungkin ada beberapa alasan untuk perasaaan demikian. Tidak semua penilaian kinerja bersifat positif, dan mendiskusikan nilai dengan pegawai yang nilainya buruk bias menjadi tidak menyenangkan. Penilaian kinerja pegawai memiliki dua pengggunaan yang umum didalam organisasi dan keduanya bisa merupakan konflik potensial. Salah satu kegunaan adalah mengukur kinerja untuk tujuan memberikan penghargaan atau dengan kata lain untuk membuat keputusan administratif mengenai si pegawai. Promosi atau pemecatan pegawai bisa tergantung hasil penilaian kinerja, yang sering membuat penilaian kinerja menjadi sulit untuk dilakukan oleh para manajer. Menurut Handoko (2010:111) penilaian kerja merupakan cara pengukuran konstribusi konstribusi dari individu dalam organisasi. Handoko (2010:113) menjelaskan tujuan dari penilaian kerja adalah:

1) Sebagai acuan untuk menentukan kompensasi, struktur upah, kenaikan gaji, promosi dan lain-lain.

2) Untuk mengindentifikasi kekuatan dan kelemahan pegawai sehingga pihak manajemen dapat menentukan orang yang tepat pada posisi pekerjaan yang ditetapkan.

3) Untuk menilai potensi yanga da di dalam diri seorang pegawai sehingga dapat merencanakan perkembangan karier lebih lanjut bagi pegawai yang bersangkutan.

4) Untuk memberikan feedback atau umpan balik kepada pegawai tentang kinerjanya.

5) Sebagai dasar untuk mempengaruhi kebiasaan pegawai.

6) Untuk meninjau dan menyelengrakan program pelatihan promosi ataupun program peltaihan lainnya.

Budiono (2010:70) menjelaskan tentang manfaat penilaian kerja pegawai, adalah:

a. Memberikan informasi mengenai hasilhasil yang diinginkan dari suatu pekerjaan.

b. Mencegah adanya miskomunikasi terkait kualitas kerja yang diharapkan.

c. Menciptakan peningkatan produktivitas pegawai dikarenakan adanya feedback/reward bagi pegawai yang berprestasi.

d. Menghargai setiap konstribusi

e. Menciptakan komunikasi dua arah antara pihak manajer dengan pegawai.

Penilaian kinerja merupakan upaya membandingkan prestasi aktual karyawan dengan prestasi kerja dengan yang diharapkan darinya (Dessler 2000). Dalam penilaian kinerja karyawan tidak hanya menilai hasil fisik, tetapi pelaksanaan 
pekerjaan secara keseluruhan yang menyangkut berbagai bidang seperti kemampuan kerja, kerajinan, kedisiplinan, hubungankerja atau hal - hal khusus sesuai bidang dan level pekerjaan yang dijabatnya. Menurut Dessler (2000) ada lima faktor dalam penilaian kinerja yang populer, yaitu

a. Prestasi pekerjaan, meliputi : akurasi, ketelitian, keterampilan, dan penerimaan keluaran.

b. Kuantitas pekerjaan, meliputi : volume keluaran dan kontribusi.

c. Kepemimpinan yang diperlukan, meliputi : membutuhkan saran, arahan atau perbaikan.

d. Kedisiplinan, meliputi : kehadiran, sanksi, warkat, regulasi, dapat dipercaya/diandalkan dan ketepatan waktu.

e. Komunikasi, meliputi : hubungan antar karyawan maupun dengan pimpinan, media komunikasi.

Gomes (1995 : 142) mengatakan ada delapan dimensi atau criteria yang perlu mendapat perhatian dalam melakukan penilaian terhadap kinerja karyawan yang berdasarkan deskripsi perilaku yang spesifik, yaitu :

a. Quantity of Work, yaitu jumlah kerja yang dilakukan dalam suatu periode waktu yang ditentukan.

b. Quality of Work, yaitu kualitas kerja yang di capai berdasarkan syarat-syarat kesesuaian dan kesiapannya.

c. Job Knowledge, yaitu luasnya pengetahuan mengenai pekerjaan dan keterampilannya.

d. Creativeness, yaitu keaslian gagasangagasan yang dimunculkan dan tindakan-tindakan untuk menyelesaikan persoalan yang timbul.

e. Coorperation, yaitu kesediaan untuk bekerjasama dengan orang lain (sesame anggota organisasi).

f. Dependability, yaitu kesadaran dan dapat dipercaya dalam hal kehadiran dan penyelesaian pekerjaan.

g. Initiative, yaitu semangat untuk melaksanakan tugas-tugas baru dan dalam memperbesar tanggung jawabnya. h. Personal Qualities yaitu menyangkut kepribadian, kepemimpinan, keramahtamahan, dan integrasi pribadi.

\subsubsection{Kepemimpinan}

Kepemimpinan merupakan inti dari pada manajemen, karena kepemimpinan merupakan motor penggerak organisasi, karena sangat pentingnya peranan kepemimpinan dalam usaha mencapai tujuan dalam suatu organisasi, sehingga dapat dikatakan bahwa keberhasilan atau kegagalan yang dialami suatu oganisasi sebagaian besar ditentukan oleh kualitas kepemimpinan yang dimiliki oleh orangorang yang diserahi tugas memimpin didalam organisasi. Manusia dalam kehidupan sehari-hari senantiasa mengalami dan merasakan kepemimpinan (leadership) dalam aneka macam bentuk, baik secara langsung maupun tidak langsung. Simamora, (2002, 24) mengemukakan tentang kepemimpinan suatu kegiatan untuk mempengaruhi perilaku orang-orang agar bekerjasama menuju kepada suatu tujuan tertentu yang mereka inginkan dalam rangka mencapai tujuan yang ditetapkan organisasi. Winardi (1999:271) menjelaskan bahwa dalam kehidupan nyata dapat di kenal bermacammacam jenis pemimpin, yaitu pemimpin formal dan informal, pemimpin dalam bidang keagamaan dan bidang pendidikan, pemimpin dalam bidang politik, dan pemimpin dalam bidang pemerintah dan bidang pendidikan. Pamudji, $(1999,132)$ menjelaskan akan definisi kepemimpinan berasal dari kata dasar pimpin yang artinya bimbing atau tuntun. Dari kara pimpin lahirlah kata kerja memimpin, yaitu berfungsi memimpin atau membimbing atau menuntut. Mulyanto, (2003, 341) menjelaskan akan definisi kepemimpinan suatu kegiatan untuk mempengaruhi perilaku orang-orang agar bekerjasama menuju kepada suatu tujuan tertentu yang mereka inginkan dalam rangka mencapai tujuan yang ditetapkan. Menurut Siagian, (1990:67) kepemimpinan adalah suatu kegiatan untuk mempengaruhi perilaku orang-orang agar bekerjasama menuju kepada suatu tujuan tertentu yang mereka inginkan bersama. 
Husnan, (1999:218) menjelaskan peranan seorang pemimpin agar dapat menjalankan tugas dan pekerjaannya dalam mengelola sumber daya manusia yang tersedia dengan baik, maka pemimpin harus mempunyai peran didalam organisasi/perusahaan untuk:

a. Memberikan kepuasan terhadap kebutuhan langsung para bawahannya.

b. Dapat menyusun "jalur" pencapaian tujuan (untuk melakukan hal ini pimpinan perlu memberikan pedoman untuk mencapai tujuan perusahaan bersamaan dengan pemuasan kebutuhan para karyawan)

c. Dapat menghilangkan hambatanhambatan pencapaian tujuan.

d. Dapat Mengubah tujuan karyawan sehingga tujuan mereka bisa berguna secara organisatoris.

Husnan, (1999:218-219) menyebutkan peranan pimpinan adalah:

a. Menentukan tujuan pelaksanaan kerja yang realistis (dalam artian kuantitas, kualitas, keamanan, dan lain sebagainnya).

b. Melengkapi karyawan dengan sumber dana guna menjalankan tugasnya.

c. Mengkomunikasikan kepada karyawan apa yang diharapkan mereka.

d. Memberikan hadiah yang sepadan untuk mendorong prestasi karyawan.

e. Mendelegasikan wewenang apabila diperlukan dan partisifasi karyawan.

f. Menghilangkan hambatan-hambatan terhadap pelaksanaan pekerjaan.

g. Menilai pelaksanaan pekerjaan dan mengkomunikasikan hasilnya.

h. Menunjukkan perhatian para karyawannya.

Menurut Winardi (1999:278), perilaku pimpinan merupakan sesuatu yang bisa dipelajari, jadi seseorang yang dilatih dengan kepemimpinan yang tepat akan bisa menjadi pemimpin yang efektif. Perilaku pemimpin disebut gaya kepemimpinan (style of leadership ).

Menurut Heidjrachman dan Husnan (1990:224), gaya kepemimpinan didefinisikan sebagai pola tingkah laku yang dirancang untuk mengintegrasikan tujuan organisasi dengan tujuan individu untuk mencapai suatu tujuan tertentu.
Menurut Hanafi (2001:364), menjelaskan tentang gaya pemimpin adalah suatu bentuk sikap dan perilaku yang dilaksanakan dalam aktivitas organisasi agar bawahan dapat melaksanakan tugas seusuai dengan yang direncanakan pemimpin.

Selain itu juga Rivai (2002:53), menjelaskan pula secara operasional dapat dibedakan lima fungsi pokok dari seorang pemimpin, yaitu :

a. Fungsi instruksi, merupakan fungsi yang bersifat komunikasi satu arah. pimpinan sebagai komunikator merupakan pihak yang menentukan apa, bagaimana, bilamana, dan dimana perintah itu dikerjakan agar keputusan dapat dilaksanakan secara efektif. Dalam hal ini fungsi pimpinan harus mempunyai sifat dan kemampuan untuk menggerakkan dan memotivasi orang lain agar mau melaksanakan perintah.

b. Fungsi Konsultasi, fungsi ini bersifat komunikasi dua arah. Dimana para pimpinan mempunyai tugas yang pertama dalam usaha menetapkan keputusan, pimpinan kerap kali memerlukan bahan pertimbangan yang mengharuskannya berkonsultasi dengan orang-orang yang dipimpinnya yang dinilai mempunyai berbagai bahan informasi yang diperlukan dalam menetapkan keputusan. Kemudian tahap berikutnya fungsi pimpinan yaitu konsultasi pimpinan dengan orang yang di pimpinnya dapat dilakukan setelah keputusan ditetapkan dan sedang dalam pelaksanaan. Konsultasi itu dimaksudkan untuk memperoleh masukan berupa umpan balik untuk memperbaiki dan menyempurnakan keputusan yang telah ditetapkan dan dilaksanakan. Dengan menjalankan fungsi konsultatif diharapkan keputusan pimpinan akan mendapatkan dukungan dan lebih mudah dalam menginstruksikannya, sehingga kepemimpinan berlangsung efektif.

c. Fungsi Partisifasi, dalam menjalankan fungsi ini pemimpin berusaha mengaktifkan orang yang di pimpinnya, baik dalam keikutsertaan 
pengambilan keputusan maupun melaksanakannya. Partisifasi tidak berarti bebas berbuat semaunya, tetapi dilakukan secara terkendali dan terarah berupa kerjasama dengan tidak mencampuri/mengambil tugas pokok orang lain. Keikutsertaan pemimpin harus tetap dalam fungsi pemimpin bukan pelaksana.

d. Fungsi Delegasi, fungsi ini dilakukan atau dilaksanakan dengan memberikan pelimpahan wewenang menetapkan keputusan, baik melalui persetujuan maupun tanpa persetujuan dari pimpinan. Fungsi pendelegasian pada dasarnya berarti kepercayaan. Orangorang penerima delegasi itu harus diyakini merupakan pembantu pemimpin yang memiliki kesamaan prinsip, persepsi, dan aspirasi.

e. Fungsi Pengendalian, fungsi ini bermaksud bahwa pemimpin yang sukses dan efektif apabila ia mempunyai fungsi dalam mengatur aktivitas, anggotanya secara terarah dan dalam koordinasi yang efektif, sehingga memungkinkan tercapainya tujuan bersama. Fungsi pengendalian dapat diwujudkan melalui kegiatan bimbingan, pengarahan, koordinasi, dan pengawasan.

Menurut Hartoyo (1997:167), ada 4 (empat) tipe/gaya pemimpin, adalah:

1) Kepemimpinan direktif merupakan suatu tipe pimpinan yang tidak ada partisipasi dari bawahannya.

2) Kepemimpinan yang mendukung, model kepemimpinan yang mempunyai kesediaan untuk menjelaskan diri, bersahabat, mudah di dekati, dan mempunyai perhatian kemanusian yang murni.

3) Kepemimpinan partisipatif, gaya kepemimpinan ini, pemimpin berusaha meminta dan mempergunakan saran dari bawahannya.

4) Kepemimpinan yang berorientasi pada prestasi, gaya kepemimpinan menetapkan tujuan yang menentang bawahannya berpartisipasi.
Menurut Hanafi (2001:370), gaya kepemimpinan dapat dikelompokkan sebagai berikut:

a. Sistem otoriter ekspoitatif

Pemimpin ini mempunyai gaya kepercayaan yang rendah terhadap bawahannya, memotivasi bawahannya melalui ancaman atau hukuman, namun kadang melalui balasan, komunikasi yang dilakukan satu arah dan membatasi pengambilan keputusan hanya untuk pemimpin saja.

b. Sistem benevolent authoritative

Pemimpin ini mempunyai gaya mempercayai bawahannya sampai tingkat tertentu, memotivasi bawahan melalui ancaman dan hukuman, membolehkan komunikasi keatas, memperhatikan ide dan pendapat dan mendelegasikan wewenang pengambilan keputusan meskipun masih melakukan pengawasan dengan ketat.

c. Sistem consultative

Pemimpin ini mempunyai gaya terhadap kepercayaan terhadap bawahan yang cukup besar, meskipun tidak sepenuhnya. Bisanya memanfaatkan pendapat atau ide dari bawahan, menggunakan balasan berupa insentif untuk memotivasi bawahan dengan kadang-kadang menggunakan ancaman dan hukuman untukmemotivasi bawahan, menjalankan komunikasi dua arah, yakni dari atas ke bawah, membuat keputusan yang umum pad atingkat atas dan membolehkan keputusan yang lebih spesifik dibuat pada tingkat bawah, dan mau berkonsultasi pada beberapa situasi.

d. Sistem Participtive

Pemimpin ini mempunyai gaya yang partisifasi, pemimpin ini mempunyai kepercayaan yang sepenuhnya terhadap karyawan, selalu memanfaatkan ide dan pendapat karyawan, menggunakan insentif ekonomi untuk memotivasi karyawan, mendorong partisifasi dalam penentuan tujuan dan penilaian kemajuan dalam pencapaian tujuan tersebut. Komunikasi dilakukan dua arah, mendorong pengambilan keputusan dalam semua bagian 
organisasi, dan menjadikan karyawan kelompok kerja.

\subsubsection{Kinerja Pegawai}

Kinerja seorang pegawai harus benar-benar maksimal dalam melaksanakan tugas, karena kalau kinerja pegawai turun, maka aktivitas pekerjaan akan kurang maksimal, oleh sebab itulah dalam menjalankan tugas seorang pegawai harus maksimal. Sri, (1997:35) menjelaskan akan definisi dari kinerja suatu kegiatan yang menghasilkan sesuatu bentuk atu juga perbandingan antara totalitas pengeluaran pada waktu tertentu dibagi totalitas masukan selama periode yang terbatas.Menurut Greenberg, (1999:63) menjelaskan akan definisi dari kinerja bahan perbandingan antara totalitas pengeluaran pada waktu tertentu dibagi totalitas masukan selama periode tertentu. Kinerja juga sikap mental yang mempunyai semangat untuk bekerja keras dan ingin memiliki kebiasaan untuk melakukan peningkatan perbaikan. Efendi (2002:76) berpendapat bahwa kinerja merupakan hasil kerja yang dihasilkan oleh pegawai atau perilaku nyata yang ditampilkan sesuai peranannya dalam organisasi. Kinerja juga berarti hasil yang dicapai seseorang baik kualitas maupun kuantitas sesuai dengan tanggungjawab yang diberi kepadanya. Selain itu kinerja seseorang dipengaruhi oleh tingkat pendidikan, inisiatif, pengalaman kerja, dan motivasi karyawan. Hasil kerja seseorang akan memberikan umpan balik bagi orang itu sendiri untuk selalu aktif melakukan pekerjaannya secara baik dan diharapkan akan menghasilkan mutu pekerjaan yang baik pula. Pendidikan mempengaruhi kinerja seseorang karena dapat memberikan wawasan yang lebih luas untuk berinisiatif dan berinovasi dan selanjutnya berpengaruh terhadap kinerjanya.

Menurut Swietenia (2009:14) manfaat kinerja pegawai antara lain adalah untuk menganalisa dan mendorong efisiensi produksi, untuk menentukan target atau sasaran yang nyata, lalu untuk pertukaran informasi antara tenaga kerja dan manajemen yang berhubungan terhadap masalah-masalah yang berkaitan.
Sedangkan menurut dari Suhardjito, (1999:3) menyebutkan 6 (enam) faktor utama menentukan kinerja tenaga kerja, yaitu:

a. Sikap kerja, merupakan kesediaan bekerja secara bergiliran (shift work), dapat menerima tambahan tugas dan bekerja satu tim atau kelompok.

b. Tingkat keterampilan merupakan suatu keharusan dalam menunjang kinerja karyawan hal ini biasa ditentukan pendidikan, latihan dan supervisi serta keterampilan dalam teknik industri.

c. Hubungan antara tenaga kerja dan pimpinan, merupakan faktor penting dalam menunjang peningkatan kinerja karena hubungan secara tidak langsung memberikan dampak yang positif terhadap peningkatan kinerja.

d. Manajemen produktivitas merupakan suatu strategi dalam mengelola efesiensi mengenai sumber-sumber dan hukum kerja.

e. Efesiensi tenaga kerja merupakan mengefesiensikan tenaga kerja melalui adanya perencanaan maupun penambahan tugas guna menunjang kinerja.

f. Kewiraswastaan merupakan penilaian terhadap pengambilan resiko, kreativitas dan usaha individu untuk memajukan diri secara sendiri guna menunjang kinerja.

Indikator kinerja karyawan menurut Bambang Guritno dan Waridin (2005) adalah

a. Mampu meningkatkan target pekerjaan.

b. Mampu menyelesaikan pekerjaan tepat waktu.

c. Mampu menciptakan inovasi dalam menyelesaikan pekerjaan

d. Mampu menciptakan kreativitas dalam menyelesaikan pekerjaan

e. Mampu maminimalkan kesalahan pekerjaan

Menurut Ruky dalam Mangkunegara (2005:19), manajemen kinerja adalah suatu bentuk usaha kegiatan atau program yang diprakarsai dan dilaksanakan oleh pimpinan organisasi atau perusahaan untuk mengarahkan dan mengendalikan prestasi karyawan. Sedangkan menurut Robert 
Bacal mendefenisikan bahwa manajemen kinerja adalah suatu proses komunikasi yang terus-menerus, dilakukan dalam kerangka kerjasama antara seorang karyawan da atasannya langsung, yang melibatkan penetapan pengharapan dan pengertian tentang fungsi kerja karyawan yang paling dasar, bagaimana pekerjaan karyawan memberikan kontribusi pada sasaran organisasi, makna dalam arti konkret untuk melakukan pekerjaan dengan baik, bagaimana prestasi kerja akan diukur, rintangan yang mengganggu kinerja dan cara untuk meminimalkan atau melenyapkan.

Menurut Timple dalam Mangkunegara (2005:15) faktor-faktor kinerja terdiri dari :

a. Faktor internal yaitu faktor yang dihubungkan dengan sifat-sifat seseorang.

b. Faktor eksternal yaitu faktor-faktor yang mempengaruhi kinerja seseorang yang berasal dari lingkungan. Seperti perilaku, sikap, dan iklim organisasi.

Menurut Mangkunegara (2005:13) menyatakan bahwa, faktor yang mempengaruhi pencapaian kinerja antara lain :

a. Faktor kemampuan (Ability)

b. Faktor motivasi

Menurut Gibson ada tiga faktor yang dapat mempengaruhi kinerja seseorang antara lain:

1. Faktor Individu : kemampuan, keterampilan, latar belakang keluarga, pengalaman tingkat sosial dan demografi seseorang.

2. Faktor Psikologis : peersepsi, peran, sikap, kepribadian, motivasi dan kepuasan kerja.

3. Faktor Organisasi : Struktur organisasi, desain pekerjaan, kepemimpinan, sistem penghargaan.

\subsection{Penelitian Terdahulu}

1. Nurulhuda, 2011,Pengaruh Pola Pikir, Penilaian dan Kepemimpinan terhadap Kinerja Pegawai Pada Kantor Pemko Banjarmasin Bidang Pemerintahan, hasil penelitian peneliti terdahulu bahwa secara simultan dan parsial semua variable berpengaruh signifikan terhadap kinerja pegawai pada. Sedangkan faktor yang berpengaruh dominan terhadap kinerja pegawai adalah pola pikir. Persamaan antara peneliti terdahulu dengan penulis adalah sama sama mengangkat masalah manajemen SDM dan teknik analisis data yang digunakan seperti uji validitas, realibilitas, uji asumsi klasik dan analisis regresi. Perbedaannya adalah obyek yang diteliti peneliti, variabel yang digunakan dan waktu pelaksanaan penelitian.

2. Muhammad Ridwan, 2012, Pengaruh Pola Pikir (Mindset), Penilaian Kerja dan Pola Kepemimpinan Terhadap Kinerja ASN Pada Kantor Kecamatan Banjarmasin Barat, dalam penelitian tersebut bahwa variable bebas mempunyai hubungan terhadap variabel terikat secara signifikan baik secara parsial maupun simultan terhadap terhadap kinerja pegawai. Persamaan peneliti adalah sama-sama membahas mengenai manajemen SDM juga sama dalan instrumen penelitian melalui validitas dan reabilitas. Perbedaannya adalah terletak pada analisis data uji persyaratan asumsi klasik sedangkan teknis analisis data menggunakan teknik analisis statistic model Analisis Regresi Linier Berganda obyek yang dijadikan sasaran penelitian, waktu penelitian, dan sasaran responden.

3. Khairunnisa, 2013, Analisis Pengaruh Kepemimpinan, Pola Pikir dan Penilaian Kerja Terhadap Kinerja Pegawai Pada Dinas Koperasi Kota Banjarmasi dalam penelitian tersebut bahwa variable bebas mempunyai hubungan signifikan baik secara parsial maupun simultan terhadap terhadap kinerja pegawai. Persamaan peneliti adalah sama-sama membahas mengenai manajemen SDM juga sama dalan instrumen penelitian melalui validitas dan reabilitas. Perbedaannya adalah terletak pada analisis data uji persyaratan asumsi klasik sedangkan teknis analisis data menggunakan teknik analisis statistic model Analisis Regresi Linier Berganda obyek yang dijadikan sasaran penelitian, waktu penelitian, dan sasaran responden. 


\section{KERANGKA KONSEPTUAL DAN HIPOTESIS}

\subsection{Kerangka Konseptual}

Pada penelitian ini bermaksud untuk menjelaskan pengaruh antar variabe $\rfloor$ melalui pengujian hipotesis dan sekaligus melakukan eksplanasi terhadap beberapa variable. Berdasarkan uraian tersebut diatas baik dari rumusan masalah, tujuan penelitian yang telah dikemukakan sebelumnya dan pendekatan teoritis, maka model kerangka konseptual tersebut dapat jelaskan dan digambarkan sebagai berikut:

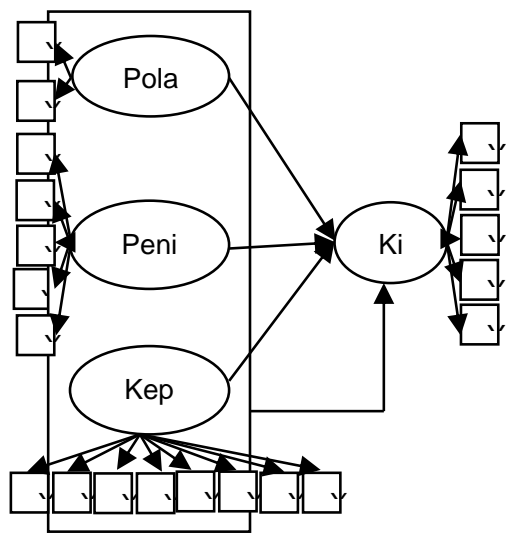

Gambar 3.1: KerangkaKonseptual

\section{Sumber Data Diolah}

Kerangka konseptual merupakan susunan atau rangkaian dari variabel bebas dan terikat, dalam menjelaskan mana yang termasuk dependent maupun independent, dimana label $\mathrm{X}$ untuk variabel bebas (independent) dan label $\mathrm{Y}$ untuk variable terikat (dependent). Dalam membaca akan kerangka konseptual didalam penelitian ini dapat digambarkan seperti adalah pola piker (mindset) (X2), penilaian kerja (X2) dan kepemimpinan (X3) merupakan independent variabel berpengaruh terhadap kinerja pegawai (Y) sebagai dependent variable. maka sifat penelitian ini adalah penelitian eksplanatori (explanatory research)

\subsection{Hipotesis Penelitian}

Adapun hipotesis dalam penelitian ini dapat dijelaskan sebagai berikut, yaitu;

1. Pola pikir (mindset), penilaian kerja dan pola kepemimpinan secara parsial terhadap kinerja ASN Pada Kantor Kecamatan Batu Mandi Kabupaten Balangan.
2. Pola pikir (mindset), penilaian kerja dan pola kepemimpinan secara simultan terhadap kinerja ASN Pada Kantor Kecamatan Batu Mandi Kabupaten Ralangan.

3. Pola pi $\mathrm{H}_{4}$ ndset) yang berpengaruh dominan terhadap kinerja ASN Pada Kantor Kecamatan Batu Mandi Kabupaten Balangan.

\section{METODE PENELITIAN}

\subsection{Rancangan Penelitian}

Pendekatan yang dilakukan dalam penelitian ini adalah pendekatan positifistik, yaitu pendekatan yang menggunakan pola pikir dedukatif dengan meihat gejala-gejala umum kemudian di lanjutkan kehal-hal yang lebuh khusus, di mana data yang dikumpulkan dari hasil kusioner dari para pegawai yang menggambarkan dan menjelaskan tentang pengaruh pola pikir (mindset), penilaian kerja dan kepemimpinan terhadap kinerja pegawai yang dihasilkannya pada Kantor Kecamatan Batu Mandi Kabupaten Balangan Kalimantan Selatan. Singarimbun \& Efendi (1995) menyatakan penelitian penjelasan merupakan bagian dari penelitian survey, dimana penalitian survey dapat digunakan untuk maksud penjajakan, deskriptif, penjelasan atau konfirmasi, evaluasi, prediksi, operasional, dan pengembangan indikator. Jenis penelitian termasuk kategori penelitian survey yaitu penelitian mengambil sample dari populasi dan menggunakan kuesioner sebagai alat pengumpul data utama. Informasi primer berkenaan dengan variabel penelitian ini dikumpulkan dengan teknik angket/kuesioner.

\subsection{Definisi Operasional dan \\ Pengukuran Variabel}

Adapun variabel akan dikumpulkan dalam penelitian ini, sebagai berikut, yaitu:

1. Variabel pola pikir (mindset) (X1) kepercayaan yang mempengaruhi sikap seseorang atau cara berpikir mempengaruhi perilaku seseorang.

2. Variabel penilaian kerja (X2) proses evaluasi seberapa baik pegawai mengerjakan pekerjaan mereka ketika dibandingkan dengan satu set standar, 
dan kemudian mengkomunikasikannya dengan para pegawai.

3. Variabel kepemimpinan (X3) suatu kegiatan untuk mempengaruhi perilaku orang-orang agar bekerjasama menuju kepada suatu tujuan tertentu yang mereka inginkan dalam rangka mencapai tujuan yang ditetapkan organisasi.

4. Variabel kinerja pegawai (Y) adalah hasil kerja secara kualitas dan kuantitas yang dicapai oleh seorang pegawai dalam melaksanakan tugasnya sesuai dengan tanggung jawab yang diberikan kepadanya. Tinggi rendahnya kinerja pekerja berkaitan erat dengan sistem pemberian penghargaan yang diterapkan oleh lembaga/organisasi tempat mereka bekerja.

\subsection{Jenis dan Sumber Data Penelitian}

\subsubsection{Jenis Data}

Adapun jenis data dalam penelitian ini yang penulis ambil, yaitu sebagai berikut:

1. Data Kualitatif, yaitu berupa data atau informasi yang tidak berbentuk angka. Penulis mengangkat data tersebut dari hasil wawancara dengan pihak kecamatan, yakni berupa data tentang sejarah instansi, struktur organisasi, bidang operasional yang dilakukan atau proses kerja.

2. Data Kuantitatif yaitu data yang berbentuk angka, yang diangkat dari dokumen instansi dalam hal ini tentang data jumlah pegawai, data tabulasi dan data lain yang berhubungan dengan penelitian.

\subsubsection{Sumber Data}

Sumber data dalam penelitian ini terdiri dari sumber data primer dan sumber data sekunder, adapun uraian data sumber data tersebut, yaitu:

1. Data Primer merupakan data penelitian yang diperoleh secara langsung dari sumber asli secara khusus di kumpulkan oleh peneliti untuk menjawab pertanyaan yang diajukan melalui daftar pertanyaan.

2. Data Sekunder merupakan data penelitian yang diperoleh secara tidak langsung melalui media perantara seperti informasi dan publikasi atau laporan historis yang telah tersusun dalam dokumen/arsip.

\subsection{Populasi dan Sampel}

4.4.1. Populasi

Dalam penelitian ini juga akan ditentukan besara populasi yang digunakan. Dimana menurut Arikunto, (1992:102) populasi adalah keseluruhan subyek penelitian. Populasi dari penelitian ini adalah pegawai kecamatan yang berjumlah 31 orang.

\subsubsection{Sampel}

Setelah ditentukan populasi dalam penelitian ini, maka kemudian ditentukan pula sampel yang digunakan dalam penelitian. Dimana menurut Sugiono, (1999:56) sampel adalah sebagian dari jumlah dan karakteristik yang dimiliki oleh suatu populasi. Sampel harus betul-betul representative agar peneliti tidak mengambil kesimpulan salah. Arikunto, (1992:104) sampel adalah sebagian atau wakil populasi yang diteliti. Sedangkan menurut Suparno, (2002:122) teknik pengambilan sample dengan menggunakan teknik probabilitas sampling adalah teknik penentuan sampel secara acak, yaitu setiap elemen populasi mempunyai probabilitas yang sama untuk terpilih sebagai sampel. Sedangkan untuk pemilihan sampel menggunakan simple random sampling yaitu pemilihan sampel acak sederhana yaitu memberikan kesempatan yang sama yang saifatnya tidak terbatas pada setiap elemen populasi untuk dipilih menjadi sampel. Sekaran $(2003 ; 102)$ menyatakan jumlah sampel yang lebih dari 30 dan kurang dari 100 sudah memadai untuk kebanyakan penelitian. Berdasarkan penjelasan tersebut, maka dalam penelitian ini semua populasi dijadikan sample, yaitu sebanyak 31 orang responden.

\subsection{Teknik Pengumpulan Data}

1. Observasi, yaitu pengumpulan data melalui pengamatan secara umum pada Kantor Kecamatan Batu Mandi Kabupaten Balangan Kalimantan Selatan sebagai dasar mengindentifikasi permasalahan yang dibahas.

2. Wawancara, yaitu mengumpulkan data dengan mengadakan tanya jawab secara lisan dengan pihak pegawai di Kantor Kecamatan Batu Mandi Kabupaten 
Balangan Kalimantan Selatan pada waktu yang ditentukan.

3. Dokumentasi, yaitu teknik pengumpulan data melalui pencatatan dan pengumpulan data instansi yang berkaitan dengan permasalahan yang akan dibahas.

4. Kuisioner, yaitu pengumpulan data dengan cara membagikan daftar pertanyaan secara tertulis kepada pegawai untuk memperoleh data primer yang diperlukan dalam penyusunan tesis ini. Kuisioner yang digunakan penulis adalah kuisioner langsung dimana peneliti langsung membagikan kuisioner kepada responden dan responden diminta untuk mengisi. Sedangkan menurut jenis dalam penyusunan itemnya digunakan kuisioner tipe pilihan dimana responden memilih salah satu jawaban yang tersedia. Tujuan dilakukannya penyebaran kuisioner langsung kepada pegawai untuk memperoleh data primer yang diperlukan dalam penyusunan tesis ini. Kuisioner yang digunakan penulis adalah kuisioner langsung dimana peneliti lantersebut adalah untuk memperoleh informasi yang relevan sesuai dengan tujuan penelitian dan untuk memperoleh informasi mengenai suatu masalah secara maksimal.

\subsection{Teknik Analisis Data}

Dalam penelitian ini teknik pengolahan data yang akan dilakukan oleh penulis adalah dengan menggunakan metode kuantitatif yakni analisis bertujuan untuk membuat diskripsi, gambaran atau lukisan secara sistematis, faktual dan akurat mengenai fakta-fakta, sifat-sifat serta hubungan antar fenomena yang diselidiki secara terperinci untuk menghasilkan rekomendasi untuk keperluan di masa yang akan datang. Selain itu adapun alat uji yang digunakan dalam penelitian ini adalah sebagai berikut:

\subsubsection{Uji Instrumen Penelitian}

\section{Uji Validitas}

Data yang terkumpul akan berguna jika instrumen penelitian yang digunakan mempunyai nilai validitas dan reliabilitas lebih besar dari rtabel yang merupakan syarat untuk mendapatkan hasil penelitian yang valid dan reliable. Sedangkan kualitas dan penelitian ditentukan oleh kualitas instrument yang digunakan. Untuk data instrumen penelitian berupa kusioner maka data dari isian pertanyaan harus valid dan reliabel karena data dari penelitian tersebut apabila kurang valid dan reliable, maka penelitian akan menjadi bias, Solimun, (2004:100). Untuk itu uji coba instrument merupakan langkah yang penting didalam penelitian. Adapun penentuan atau pengambilan keputusan untuk valid instrumen pertanyaan adalah Jika rhitung positif dan rhitung > rtabel maka instrument tersebut valid. Jika rtabel negative dan rhitung < rtabel maka instrument tersebut tidak valid.

\section{Uji Reliabilitas}

Instrument yang reliable artinya konsisten atau stabil yang bila digunakan untuk mengukur obyek yang sama, akan menghasilkan data yang sama. Pratisto, (2004:241). Uji validilitas dan reliabilitas menurut Pratisto (2004:249-257) dapat dilakukan dengan menggunakan one shot method sering disebut dengan pengujian internal consistency dengan metode ini pengukuran cukup dilakukan satu kali. Selain itu adapula teknik penilaian lain, yaitu uatu konstruk atau variabel dikatakan reliabel jika memberikan nilai Cronbach Alpha > 0,60. (Ghozali, 2006, 41-42)

\subsubsection{Uji Asumsi Klasik 1. Uji Multikolinearitas}

Multikolinearitas adalah keadaan dimana variabel-variabel independen dalam persamaan regresi mempunyai korelasi (hubungan) yangerat satu sama lain. Jika terjadi korelasi, maka dinamakan terdapat problem multikolinearitas. Untuk mengetahui ada tidaknya problem Multikolinearitas, parameter yang mudah ditenggarai dari adanya Multikolinearitas, adalah Deteksi terhadap gangguan multikolinearitas dapat dilihat dari nilai VIF (variance inflation factor) dan nilai tolerance (Pratsito, 2004, 156-161). Tolerance menguur variabilitas variable bebas yang terpilih yang tidak dapat dijelaskan oleh variable bebas lainnya. Jadi 
ilai tolerance yng rendah sama dengan nilai VIF tinggi (karena VIF $=1 /$ tolerance) dan menunjukkan adanya koloniritas yang tinggi. Multikolineritas dapat diketahui dengan memeriksa nilai VIF (variance inflation factor) yang merupakan unsure diagonal invers matrk korelasi sederhana antara perubah bebas. Apabila beberapa nilai VIF lebih dari $10 \mathrm{mk}$ multikolienearitas adalah sebuah masalah. Solimun, (2004:35).

\section{Uji Heteroskedastisitas}

Salah satu asumsi klasik dalam model regresi berganda ialah bhawa kesalahan pengganggu (residual) mempunyai varian (ragam) yang sama dari satu pengataman kepengamatan lain (antara variable), asumsi ini disebut homokedastisitas. Supranto, (1995:43), menurut Pratisto (2004:155) adalah dengan melihat pola diagram pencar. Nilai dari diagram pencar yag residu dapat dilihat dari selisih antara nilai $\mathrm{Y}$ prediksi dengan $\mathrm{Y}$ observasi jika diagram pencar yang membentuk pola-pola tertentu yang teratur maka regresi mengalami gangguan heteroskedastisitas. Dan jika diagram pencar tidak membentuk pola atau acak maka regresi tidak mengalami gangguan heteroskedastisitas.

\section{Uji Normalitas (kenormalan)}

Menurut Solimun (2004:33) NID (normal independent distributed), yaitu berdistribusi normal atau saling bebas. Asumsi ini berarti bahwa kesalahan mengikuti sebaran normal dengan nilai tengah nol (0) dan ragam konstan (J). Solimun (2004, 46) dapat dilakukan dengan cara membuat plot antara skor normal dengan data observasi dan melihat penyebaran data (titik) pada sumbu diagonal dari grafik. Bilamana hasil plot menujukkan pola garis lurus mendekati $45^{\circ}$ berarti asumsi normalitas terpenuhi.

\subsubsection{Uji Hipotesis}

\section{Analisis Regresi Linier Berganda}

Analisis data dilakukan berdasarkan data primer yang diperoleh langsung dari penyebaran kuisioner kepada pegawai yang selanjutnya akan dianalisis dengan paket program SPSS melalui bantuan program komputer. Untuk menguji hipotesa dalam penelitian ini menggunakan analisis regresi linier berganda. Adapun rumus dari regresi linier berganda adalah sebagai berikut:

$\begin{array}{ll}\mathbf{Y}=\mathbf{a}+\boldsymbol{\beta 1} \mathbf{. X 1} & +\boldsymbol{\beta 2} \cdot \mathbf{X} \mathbf{2}+\boldsymbol{\beta 3} \cdot \mathbf{X} 3+\boldsymbol{\varepsilon} \\ \text { Dimana : } & \\ \mathrm{Y} & =\text { Kinerja pegawai } \\ \mathrm{X} 1 & =\text { Pola Pikir (mindset) } \\ \mathrm{X} 2 & =\text { Penilaian kerja } \\ \mathrm{X} 3 & =\text { Kepemimpinan } \\ \varepsilon & =\text { Faktor gangguan } \\ \beta 11,2,3 & =\text { Koefsien regresi } \\ \mathrm{a} & =\text { Konstanta }\end{array}$

\section{Uji F (simultan)}

Uji $F$ digunakan untuk mengetahui signifikan atau tidaknya pengaruh variabel bebas (X) secara bersama-sama terhadap variabel terikat (Y). Adapun langkahlangkah pengujiannya sebagai berikut menentukan taraf nyata dan $\mathrm{F}$ table taraf nyata $5 \%(0,05)$ Derajat pembilang $\left(\mathrm{db}_{1}\right)=$ $\mathrm{k}-1$; Derajat penyebut $\left(\mathrm{db}_{2}\right) \quad=\mathrm{n}-\mathrm{k}$. Menarik kesimpulan $\mathrm{H}_{0}$ diterima atau ditolak berdasarkan pada hasil perbandingan antara F-hitung dengan Ftabel dengan kreteria pengujian apabila $\mathrm{F}$ hitung > F-tabel, maka $\mathrm{H}_{0}$ ditolak atau $\mathrm{H}_{1}$ diterima. dan apabila F-hitung < F-tabel, maka $\mathrm{H}_{0}$ diterima atau $\mathrm{H}_{1}$ ditolak.

\section{Uji Parsial (Uji t)}

Uji $\mathrm{t}$ dilakukan untuk menguji tingkat signifikan variabel bebas (X) secara individu/parsial terhadap variabel terikat (Y). Adapun langkah langkah pengujian sebagai berikut menentukan taraf nyata dan $\mathrm{t}$ table taraf nyata $5 \%(0,05)$ Pada $t$ table $\mathrm{db}$ $=\mathrm{n}-\mathrm{k}$ dan menarik kesimpulan $\mathrm{H}_{0}$ diterima atau ditolak berdasarkan pada hasil perbandingan antara F-hitung dengan Ftabel dengan kreteria pengujian apabila thitung > t-tabel, maka $\mathrm{H}_{0}$ ditolak atau $\mathrm{H}_{1}$ diterima dan apabila t-hitung < t-tabel, maka $\mathrm{H}_{0}$ diterima atau $\mathrm{H}_{1}$ ditolak.

\section{Uji Dominan}

Untuk mengkaji variabel yang dominan digunakan indikator koefisien beta standardized dari variabel-variabel dari model regresi. Koefisien beta standardized diperoleh dari hasil perkalian antara koefisien parsial korelasi ( $\left.\mathrm{SDx}_{1} / \mathrm{Sdy}\right)$ dan koefisien variabelnya (bi). Selain itu Pratisto (2004:160) keeratan hubungan 
variabel dapat diambil dari t hitung dengan standar t tabel.

\section{ANALISIS HASIL PENELITIAN DAN PEMBAHASAN}

\subsection{Analisis Hasil Penelitian}

\subsubsection{Pengujian Instrumen Penelitian}

Ketepatan hipotesis sangat bergantung pada data yang dipergunakan dalam pengujian tersebut untuk itu digunakan analisis data dan pembahasan beberapa uji data, yaitu:

\section{Uji Validitas}

Uji validitas dapat diketahui melihat nilai rhitung dan untuk mengetahui validitas instrument pertanyaan harus dibandingkan dengan rtabel pada $\alpha 0,05$.

\section{Tabel 5.11}

Rekapitulasi Hasil Uji Validitas Variabel Pola Pikir (mindset) (X1)

\begin{tabular}{|c|c|c|}
\hline Variable & rhitung & Rtabel \\
\hline $\mathrm{X} 1.1$ & $0,430(* *)$ & 0,355 \\
$\mathrm{X} 1.2$ & $0,454(* *)$ & 0,355 \\
\hline
\end{tabular}

Sumber : data primer diolah (lihat lampiran 3)

Rekapitulasi hasil uji validitas terhada instrumen pertanyaan variabel pola pikir (mindset) (X1) yang diajukan terlihat dari 31 responden terdapat nilai Table $r$ (Pearson Product Moment) uji 2 sisi taraf signifikan 0,05 nilai rhitung sebesar 0,355 . Berdasarkan hal itu bila dibandingkan antara rhitung dengan rtabel tersebut, maka dapat disimpulkan bahwa semua instrumen pertanyaan tersebut valid, ini terbukti nilai rhitung positip dan rhitung > rtabel, maka semua instrumen dari pertanyaan variabel pola pikir (mindset) (X1) pada Kecamatan Batu Mandi Kabupaten Balangan Kalimantan Selatan tersebut valid.

\section{Tabel 5.12}

\section{Rekapitulasi Uji Validitas}

Variabel Penilaian Kerja (X2)

\begin{tabular}{|c|c|c|}
\hline Variable & rhitung & rtabel \\
\hline $\mathrm{X} 2.1$ & $0,511(* *)$ & 0,355 \\
$\mathrm{X} 2.2$ & $0,460(* *)$ & 0,355 \\
$\mathrm{X} 2.3$ & $0,482(* *)$ & 0,355 \\
$\mathrm{X} 2.4$ & $0,423(* *)$ & 0,355 \\
$\mathrm{X} 2.5$ & $0,414(* *)$ & 0,355 \\
\hline
\end{tabular}

Sumber : data primer diolah (lihat lampiran 3)

Rekaputilasi hasil uji validitas terhadap instrumen pertanyaan variabel penilaian
(X2) yang diajukan terlihat dari 31 responden terdapat nilai Table $\mathrm{r}$ (Pearson Product Moment) 2 sisi taraf signifikan 0,05 nilai rhitung sebesar 0,355 .

Berdasarkan hal itu bila dibandingkan antara rhitung dengan rtabel tersebut, maka disimpulkan bahwa semua instrumen pertanyaan tersebut valid, ini terbukti nilai rhitung positip dan rhitung > rtabel, maka semua instrumen dari pertanyaan variabel penilaian kerja (X2) pada Kecamatan Batu Mandi Kabupaten Balangan Kalimantan Selatan tersebut valid.

Table 5.13

Rekapitulasi Uji Validitas

Variabel Kepemimpinan (X3)

\begin{tabular}{|c|c|c|}
\hline Variable & rhitung & rtabel \\
\hline X31 & $0,418(* *)$ & 0,355 \\
X3.2 & $0,533(* *)$ & 0,355 \\
X3.3 & $0,400(* *)$ & 0,355 \\
X3.4 & $0,499(* *)$ & 0,355 \\
X3.5 & $0,507(* *)$ & 0,355 \\
X3.6 & $0,516(* *)$ & 0,355 \\
X3.7 & $0,508(* *)$ & 0,355 \\
X3.8 & $0,444(* *)$ & 0,355 \\
\hline
\end{tabular}

Sumber : data primer diolah (lihat lampiran 3)

Hasil uji validitas terhadap instrumen pertanyaan variabel kepemimpinan (X3) yang diajukan terlihat dari 31 responden terdapat nilai Table $\mathrm{r}$ (Pearson Product Moment) 2 sisi taraf signifikan 0,05 nilai rhitung sebesar 0,355 .

Berdasarkan hal itu bila dibandingkan antara rhitung dengan rtabel tersebut, maka dapat disimpulkan bahwa semua instrumen pertanyaan tersebut valid, ini terbukti nilai rhitung positip dan rhitung > rtabel, maka semua instrumen dari pertanyaan variabel kepemimpinan (X3) pada Kecamatan Batu Mandi Kabupaten Balangan Kalimantan Selatan tersebut valid. 
Table 5.14

Rekapitulasi Uji Validitas

Variabel Kinerja Pegawai (Y)

\begin{tabular}{|c|c|c|}
\hline Variable & rhitung & rtabel \\
\hline Y11 & $0,440(* *)$ & 0,355 \\
Y1.2 & $0,450\left(^{* *}\right)$ & 0,355 \\
Y1.3 & $0,555\left(^{* *}\right)$ & 0,355 \\
Y1.4 & $0,535(* *)$ & 0,355 \\
Y1.5 & $0,411(* *)$ & 0,355 \\
\hline
\end{tabular}

Sumber : data primer diolah (lihat lampiran 3)

Hasil uji validitas terhadap instrumen pertanyaan variabel kinerja pegawai $(\mathrm{Y})$ yang diajukan terlihat dari 31 responden terdapat nilai Table $\mathrm{r}$ (Pearson Product Moment) 2 sisi taraf signifikan 0,05 nilai rhitung sebesar 0,355 .

Berdasarkan hal itu bila dibandingkan antara rhitung dengan rtabel tersebut, maka dapat disimpulkan bahwa semua instrumen pertanyaan tersebut valid, ini terbukti nilai rhitung positip dan rhitung > rtabel, maka semua instrumen dari pertanyaan variabel kinerja pegawai (Y) pada Kecamatan Batu Mandi Kabupaten Balangan Kalimantan Selatan tersebut valid.

\section{Uji Reliabilitas}

Suatu konstruk atau variabel dikatakan reliabel jika memberikan nilai Cronbach Alpha minimum 0,5. (Santoso, 2004, 280). Suatu konstruk atau variabel dikatakan reliabel jika memberikan nilai Cronbach $A_{\text {lpha }}>0,60$. (Ghozali, 2006, 41-42).

Berikut ringkasan hasil uji reliabilitas instrumen dalam penelitian ini, yaitu :

\section{Tabel 5.15}

Hasil Uji Reliabilitas

\begin{tabular}{|l|c|c|}
\hline \multicolumn{1}{|c|}{ Variable } & $\begin{array}{c}\text { Cronbach } \\
\mathrm{A}_{\text {lpha }}\end{array}$ & $\begin{array}{c}\text { Nilai } \\
\text { Baku }\end{array}$ \\
\hline Pola Pikir & 0,660 & 0,60 \\
(muindset) (X1) & 0,675 & 0,60 \\
Penilaian Kerja & 0,667 & 0,60 \\
(X2) & 0,680 & 0,60 \\
Kepemimpinan & & \\
(X3) & & \\
Kinerja Pegawai & & \\
(Y) & & \\
\hline
\end{tabular}

Sumber : data primer diolah (lihat lampiran 4)
Setelah dilakukan pengujian terhadap variabel bebas dan terikat pada Kecamatan Batu Mandi Kabupaten Balangan Kalimantan Selatan, maka reliabilitas diketahui semua nilai Cronbach $A_{\text {lpha }}$ lebih besar dari nilai baku, maka hasil dari jawaban kuesioner adalah reliabel.

\subsubsection{Pengujian Asumsi Klasik}

1. Uji Multikolinearitas

Uji multikolinearitas bertujuan untuk menguji apakah model regresi yang digunakan telah di temukan adanya korelasi (hubungan) antara variabel bebas (independent) yang satu dengan variabel bebas yang lainnya. Berikut hasil uji multikolinearitas adalah :

Tabel 5.16

Hasil Uji Multikolinearitas

\begin{tabular}{|c|c|c|}
\hline \multirow{2}{*}{ Variabel } & \multicolumn{2}{|c|}{ Collinierarity Statistic's } \\
\cline { 2 - 3 } & Tolerance & VIF \\
\hline X1 & 0,990 & 1,378 \\
\hline X2 & 0,956 & 1,135 \\
\hline X3 & 0,989 & 1,255 \\
\hline
\end{tabular}

Sumber : data primer diolah (lihat lampiran 5)

Hasil perhitungan nilai tolerance pada tabel diatas menunjukkan nilai yang mendekati angka 1 dan nilai variance inflation factor (VIF) diatas menunjukkan tidak ada satu variabel bebas yang memiliki nilai VIF tidak lebih dari 10. Jadi dapat disimpulkan asumsi tidak disifat adanya gejala multikolinearitas antar variabel bebas dalam model regresi.

\section{Uji Heteroskedastisitas}

Uji heteroskedastisitas bertujuan untuk menguji apakah dalam model regresi terjadi ketidaksamaan varian (ragam) dari residual atau pengamatan lain. Menurut Pratisto (2004, 155) adalah dengan melihat pola diagram pencar. Nilai dari diagram pencar yang residual dapat dilihat dari selisih antara nilai Y prediksi dengan Y observasi. (1) Jika diagram pencar yang membentuk pola tertentu yang teratur, maka regresi mengalami ganguan heteroskedastisitas. (2) Jika diagram pencar tidak membantuk pola atau acak, maka regresi mengalami tidak ganguan heteroskedastisitas. 
Adapun hasil heteroskedastisitas tersebut, adalah sebagai berikut:



Gambar 5.2 : Diagram Pencar Hasil

Heteroskedastisitas

Sumber : data primer diolah (lihat lampiran 5)

Dalam diagnose heteroskedastisitas di penelitian ini menghasilkan grafik scatterplot menghasilkan penyebaran dalam bentuk pola atau acak, maka hal ini dapat disimpulkan bahwa regresi layak dipergunakan.

\section{Uji Normalitas (kenormalan)}

Uji normalitas dilakukan untuk mengetahui apakah variabel terikat dan variabel bebas dalam sebuah model regresi mempunyai distribusi normal atau tidak. Berdasakan hasil pengujian dengan SPSS, diperoleh grafik Plot of Regression, yaitu:

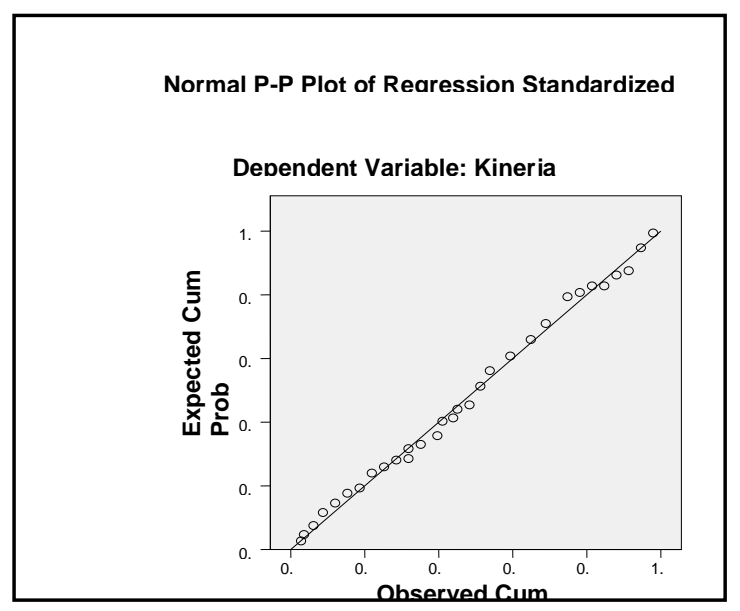

Gambar 5.3 : Grafik Plot of Regression Sumber : data primer diolah (lihat lampiran 5)
Terlihat titik penyebaran disekitar garis diagonal / menunjukkan pola garis lurus mendekati sudut $45^{\circ}$, maka di dapat bahwa semua data berdistribusi normal, sehingga asumsi normalitas terpenuhi.

\subsubsection{Analisis Regresi}

Untuk menjawab hipotesis, maka perlu diajukan analisis model regresi linier berganda menggunakan alat bantu analisis berupa program SPSS 17 for wndows.

Untuk itu adapun hasil uji parsial diketahui dengan melihat data pada tabel berikut ini:

\section{Tabel 5.17}

\section{Hasil Uji Regresi Berganda} Coefficients(a)

\begin{tabular}{|c|c|c|c|c|c|c|c|}
\hline & \multicolumn{2}{|c|}{$\begin{array}{l}\text { Unstandar } \\
\text { dized } \\
\text { Coefficien } \\
\text { ts }\end{array}$} & \multirow[t]{2}{*}{$\begin{array}{c}\text { Standar } \\
\text { dized } \\
\text { Coeffic } \\
\text { ients } \\
\end{array}$} & \multirow[b]{2}{*}{$\mathrm{t}$} & \multirow[b]{2}{*}{$\begin{array}{l}\mathrm{Si} \\
\mathrm{g} .\end{array}$} & \multicolumn{2}{|c|}{$\begin{array}{c}\text { Collinearity } \\
\text { Statistics }\end{array}$} \\
\hline & $\mathrm{B}$ & $\begin{array}{l}\text { Std } \\
\cdot \\
\text { Err } \\
\text { or }\end{array}$ & & & & $\begin{array}{l}\text { Toler } \\
\text { ance }\end{array}$ & $\begin{array}{l}\text { VI } \\
\mathrm{F}\end{array}$ \\
\hline (Constan & 20,4 & 4,1 & & 4,8 & , 0 & & \\
\hline t) & 54 & 80 & & 93 & 01 & & \\
\hline Pola & & & & & & & \\
\hline Pikir & 883 &, 10 & 880 & 8,4 &, 0 & 990 & 1,3 \\
\hline $\begin{array}{l}\text { (mindset } \\
\text { ) }(\mathrm{X} 1)\end{array}$ & & 5 & & 09 & 00 & & 78 \\
\hline Penilaian & & ,12 & & 6,1 & , 0 & & 1,1 \\
\hline $\begin{array}{l}\text { Kerja } \\
\text { (X2) }\end{array}$ & ,756 & 2 & ,736, & 96 & 02 & 956, & 35 \\
\hline Kepemi & 801 & ,10 & 708 & 7,4 & ,0 & 89 & 1,2 \\
\hline $\begin{array}{l}\text { mpinan } \\
\text { (X3) }\end{array}$ & , & 7 & , 198 & 85 & 01 & 989, & 55 \\
\hline
\end{tabular}

a Dependent Variable: Kinerja Pegawai (Y)

Sumber : data primer diolah (lihat lampiran 5)

Berdasarkan dari penjelasan dan hasil regresi tersebut diperoleh persamaan regresi sebagai berikut :

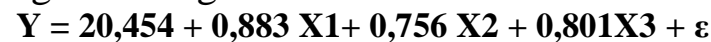

\subsubsection{Uji Hipotesis}

Selanjutnya untuk mengevaluasi dan menguji hipotesis secara simultan, yaitu:

\section{Uji hipotesis Pertama}

Pola pikir (mindset) berpengaruh signifikan terhadap kinerja pegawai pada Kantor Kecamatan Batu Mandi Kabupaten Balangan Kalimantan Selatan

Kemudian untuk menguji hipotesis parsial dengan membandingkan nilai thitung dengan ttable pada taraf nyata 5\%. Jika thitung > ttable maka pengaruhnya signifikan. Untuk mendapatkan ttabel digunakan tabel distribusi t untuk tingkat signifikasi 5\% dengan Degrees of Freedom 
(df) = n-k maka didapat df adalah (31-4)= 27 dengan demikian ttabel adalah sebesar 1,703. Secara parsial untuk pola pikir (mindset) (X1) berpengaruh terhadap kinerja pegawai (Y) hal ini didasarkan pada perbandingan antara thitung 8,409 dan ttabel 1,703, berarti terdapat pengaruh signifikan antara variabel pola pikir (mindset) (X1) dengan variabel terikat kinerja pegawai (Y) pada Kantor Kecamatan Batu Mandi Kabupaten Balangan Kalimantan Selatan. Berdasarkan hal tersebut, maka hipotesis pertama diterima. Besarnya pengaruh dari variabel pola pikir (mindset) (X1) terhadap status kinerja pegawai (Y) pada Kantor Kecamatan Batu Mandi Kabupaten Balangan Kalimantan Selatan dapat diketahui dari Standardized Coefficients Beta 0,880 yang berarti pola pikir (mindset) ini memberikan pengaruh terhadap kinerja pegawai sebesar $88 \%$.

\section{Uji Hipotesis Kedua}

Penilaian kerja berpengaruh signifikan terhadap kinerja pegawai pada Kantor Kecamatan Batu Mandi Kabupaten Balangan Kalimantan Selatan

Kemudian untuk variabel penilaian kerja (X2) berpengaruh signifikan terhadap kinerja pegawai (Y) pada Kantor Kecamatan Batu Mandi Kabupaten Balangan Kalimantan Selatan hal ini didasarkan pada perbandingan antara thitung 6,196 dan ttabel 1,703 berarti terdapat pengaruh antara variabel penilaian kerja (X2) dengan variabel terikat kinerja pegawai (Y) pada Kantor Kecamatan Batu Mandi Kabupaten Balangan Kalimantan Selatan. Berdasarkan hal tersebut, maka hipotesis kedua diterima. Besarnya pengaruh dari variabel penialain kerja (X2) terhadap kinerja pegawai (Y) pada Kantor Kecamatan Batu Mandi Kabupaten Balangan Kalimantan Selatan dapat diketahui dari Standardized Coefficients Beta 0,736 yang berarti penilaian kerja ini memberikan pengaruh terhadap kinerja pegawai sebesar $73,6 \%$.

\section{Uji Hipotesis Ketiga}

Kepemimpinan berpengaruh signifikan terhadap kinerja pegawai pada Kantor
Kecamatan Batu Mandi Kabupaten Balangan Kalimantan Selatan.

Kemudian untuk variabel kepemimpinan (X3) berpengaruh signifikan terhadap kinerja pegawai (Y) pada Kantor Kecamatan Batu Mandi Kabupaten Balangan Kalimantan Selatan hal ini didasarkan pada perbandingan antara thitung 7,485 dan ttabel 1,703 berarti terdapat pengaruh antara variabel kepemimpinan (X3) dengan variabel terikat kinerja pegawai (Y) pada Kantor Kecamatan Batu Mandi Kabupaten Balangan Kalimantan Selatan. Berdasarkan hal tersebut, maka hipotesis ketiga diterima. Besarnya pengaruh dari variabel kepemimpinan (X3) terhadap kinerja pegawai (Y) pada Kantor Kecamatan Batu Mandi Kabupaten Balangan Kalimantan Selatan dapat diketahui dari Standardized Coefficients Beta 0,798 yang berarti penilaian kerja ini memberikan pengaruh terhadap kinerja pegawai sebesar 79,8\%.

\section{Uji Hipotesis Keempat}

Pola pikir (mindset). penilaian kerja dan kepemimpinan berpengaruh signifikan secara simultan terhadap kinerja pegawai pada Kantor Kecamatan Batu Mandi Kabupaten Balangan. Uji F (simultan) ini digunakan dengan tujuan untuk membuktikan apakah variabel bebas seperti pola pikir (mindset) (X1), penilaian kerja (X2) dan kepemimpinan (X3) berpengaruh secara bersama-sama terhadap variabel terikat yaitu kinerja pegawai (Y) pada Kantor Kecamatan Batu Mandi Kabupaten Balangan Kalimantan Selatan.Untuk menilai Uji F, maka perlu ditampilkan data ANOVA berikut ini: 
Tabel 5.18

ANOVA(b)

\begin{tabular}{|l|r|r|c|c|}
\hline & & Mean & & \\
& Df & Square & F & Sig. \\
\hline Regression & 3 & 62,358 & 7,281 &, $000(\mathrm{a})$ \\
Residual & 28 & 8,564 & & \\
Total & 31 & & & \\
\hline
\end{tabular}

a Predictors: (Constant), Pola Pikir

(mindset) (X1), Penilaian Kerja (X2),

Kepemimpinan (X3)

b Dependent Variable: Kinerja Pegawai

(Y)

Sumber : data primer diolah (lihat lampiran 5)

Hasil regresi pada tabel ANOVA(b) memperlihatkan bahwa Fhitung adalah 7,281 sedangkan nilai Ftable dengan tingkat signifikan 5\%. Sedangkan untuk menghitung uji $\mathrm{F}$ digunakan program SPSS. Penentuan nilai Fhitung dengan cara menentukan Derajat bebas bagi pembilang (numerator) adalah (k-1) sehingga didapat $(4-1)=3$, sedangkan derajat kebebasan bagi pembagi (denumerator) adalah (n-k) sehingga didapat $(31-4)=27$. Dengan demikian didapat Ftabel dengan numerator = 3 dan denumurator 27 sebesar 2,960. Berdasarkan hal tersebut diperoleh di dapat Fhitung $(7,281)>$ Ftabel $(2,960)$ yang berarti variabel bebas yang terdiri dari seperti pola pikir (mindset) (X1), penilaian kerja (X2) dan kepemimpinan (X3) berpengaruh secara bersama-sama terhadap variabel terikat yaitu kinerja pegawai $(\mathrm{Y})$ pada Kantor Kecamatan Batu Mandi Kabupaten Balangan Kalimantan Selatan, berdasarkan hal tersebut, maka hipotesis keempat diterima.Untuk regresi dengan lebih dari dua variabel bebas digunakan $R$ Square sebagai keofesien diterminan. Terlihat $R$ Square sebesar 0,886 disini berarti $88,6 \%$ variasi kinerja pegawai $(\mathrm{Y})$ pada Kantor Kecamatan Batu Mandi Kabupaten Balangan Kalimantan Selatan bisa dijelaskan oleh variabel seperti pola pikir (mindset) (X1), penilaian kerja (X2) dan kepemimpinan (X3) sedangkan sisanya dari $(100 \%-88,6 \%)=11,4 \%$ dijelaskan oleh variabel lain yang tidak dianalisis pada penelitian ini seperti faktor budaya organisasi, kedisiplinan dan lain-lain.

\subsection{Pembahasan}

1. Pola pikir (mindset), penilaian kerja dan pola kepemimpinan secara parsial terhadap kinerja ASN Pada Kantor Kecamatan Batu Mandi Kabupaten Balangan

Hasil pengujian hipotesis pertama diketahui bahwa pola pikir (mindset), penilaian kerja dan pola kepemimpinan secara parsial terhadap kinerja ASN Pada Kantor Kecamatan Batu Mandi Kabupaten Balangan, hasil ini sejalan dengan penelitian Nurulhuda, 2011, Pengaruh Pola Pikir, Penilaian dan Kepemimpinan terhadap Kinerja Pegawai Pada Kantor Pemko Banjarmasin. Berdasarkan hal tersebut, maka pihak instansi perlu lebih memperbaiki pola pikir pegawai sesuai serta teori menurut Mulyadi (2007:71), mindset merupakan sikap mental mapan yang di bentuk melalui pendidikan, pengalaman dan prasangka, dengan cara:

a. Pola pikir pegawai perlu dikembangkan dengan menanamkan pada pegawai baik melalui diklat maupun dalam praktek kerja setiap hari, dengan cara :

1) Menanamkan kepada para pegwai bahwa ekerja sebagai ibadah

2) Menanamkan kepada para pegawai untuk selalu menghindari sikap tidak terpuji.

3) Menanamkan kepada para pegawai bahwa bekerja harus dilakukan secara profesional.

4) Selalu berusaha meningkatkan kompetensi diri secara terus menerus.

5) Tanamkan kepad apra pegawai sebagai pelayan dan pengayom bagi masyarakat.

6) Menanamkan kepada para pegawai untuk selalu bekerja sesuai dengan peraturan yang berlaku.

7) Selalu berusaha mengembangkan pola pikir pegawai selalu terbuka dan selalu bersikap realistis dalam bekerja.

8) Penilaian kerja berpengaruh signifikan terhadap kinerja pegawai pada Kantor Kecamatan Batu Mandi Kabupaten Balangan Kalimantan Selatan

b. Penilaian kerja berpengaruh signifikan terhadap kinerja pegawai pada Kantor Kecamatan Batu Mandi Kabupaten Balangan Kalimantan Selatan ini sesuai dengan teori menurut Hasibuan 
(2000:87) menjelaskan tentang penilaian kerja adalah kegiatan untuk mengevaluasi perilaku dari prestasi kerja pegawai serta menetapkan kebijaksanaan selanjutnya, berdasarkan hasil penelitian tersebut, hendaknya pihak instansi dapat lebih meningkatkan kembali akan variabel penilaian kerja terhadap pegawai hal ini penting karena penilaian kerja akan dapat mengevaluasi dan menilai akan prestasi pekerjaan pegawai, dapat menilai kuantitas pekerjaan pegawai, dapat membantu pemimpinan dalam mengelola bawahan, dapat menilai kedisiplinan pegawai dan dapat mengevaluasi komunikasi hubungan antar pegawai maupun dengan pimpinan. Adapun unsur yang dapat dinilai dalam penilaian pelaksanaan kerja pegawai adalah: Kesetiaan, Prestasi keja, Tanggungjawab, Ketaatan, Kejujuran, Kerjasama, Prakarsa dan Kepemimpinan

Untuk itulah pihak Kecamatan perlu dan harus selalu melakukan penilaian kepada para pegawai, penilaian dilakukan oleh pejabat penilai seperti atasan langsung yang bisa dilakukan dengan waktu yang ditentukan seperti perbulan, persemester maupun pertahun.

c. Kepemimpinan berpengaruh signifikan terhadap kinerja pegawai pada Kantor Kecamatan Batu Mandi Kabupaten Balangan Kalimantan Selatan ini sejalan berdasarkan teori menurut Simamora, (2002, 24) mengemukakan tentang kepemimpinan suatu kegiatan untuk mempengaruhi perilaku orang-orang agar bekerjasama menuju kepada suatu tujuan tertentu yang mereka inginkan dalam rangka mencapai tujuan yang ditetapkan organisasi. Pemimpin dalam organisasi merupakan salah satu unsur yang menentukan atas berhasil atau tidaknya suatu organisasi. Selain itu pemimpin merupakan inti dari pada manajemen, karena pemimpin merupakan motor penggerak bagi sumber dan alat-alat didalam suatu organisasi, sehingga dapat dikatakan bahwa keberhasilan atau kegagalan yang di alami suatu organisasi sebagian besar ditentukan oleh kualitas pemimpin yang di miliki oleh orangorang yang di serahi tugas untuk memimpin organisasi tersebut. Oleh sebab itulah fungsi penggerakan ialah suatu fungsi pembimbingan dan pemberian pimpinan serta menggerakkan orang agar orang atau sekelompok orang suka dan mau bekerja, fungsi ini adalah fungsi yang sangat penting sebab biar bagaimanapun juga baik suatu perencanaan serta tertib dan baiknya suatu organisasi belum dapat menjamin bergeraknya organisasi kearah tujuannya.

Untuk itu pimpinan kecamatan perlu meningkatkan kembali akan perananya sebagai pimpinan adalah:

1) Dengan selalu berkomitmen dalam menentukan tujuan pelaksanaan kerja yang realistis.

2) Selalu berkmitmen yang kuat dalam memperhatikan dan melengkapi bawahannya dengan sumber dana guna menjalankan tugasnya.

3) Selalu berusaha dalam menjaga komunikasikan kepada bawahan apa yang diharapkan mereka.

4) Dapat memperhatikan dan memberikan hadiah yang sepadan untuk mendorong prestasi pegawai.

5) Dapat mendelegasikan wewenang apabila diperlukan dan partisifasi pegawai.

6) dapat menghilangkan hambatanhambatan terhadap pelaksanaan pekerjaan.

7) Dapat menilai pelaksanaan pekerjaan dan mengkomunikasikan hasilnya secara adil.

8) Selalu menunjukkan perhatian para pegawainya dalam lingkup pekerjaan.

2. Pola pikir (mindset). penilaian kerja dan kepemimpinan berpengaruh signifikan secara simultan terhadap kinerja pegawai pada Kantor Kecamatan Batu Mandi Kabupaten Balangan

Hasil pengujian hipotesis ke dua diketahui bahwa pola pikir (mindset). penilaian kerja dan kepemimpinan berpengaruh signifikan secara simultan terhadap kinerja pegawai 
pada Kantor Kecamatan Batu Mandi Kabupaten Balangan, penelitian ini sejalan dengan hasil penelitian Khairunnisa, 2013, Analisis Pengaruh Kepemimpinan, Pola Pikir dan Penilaian Kerja Terhadap Kinerja Pegawai Pada Dinas Koperasi Kota Banjarmasin, berdasarkan hal tersebut, maka hendaknya pihak Kecamatan dapat selalu memperhatikan dan memfokuskan peningkatan pola pikir kepada pegawai, selalu melaksanakan penilaian kerja secara berkala maupun dapat menciptakan peranan pimpinan yang baik dalam mengelola bawahan agar kinerja pegawai dapat selalu ditingkatkan sesuai dengan harapan organisasi.

\section{Pola pikir (mindset) yang berpengaruh dominan terhadap kinerja ASN Pada Kantor Kecamatan Batu Mandi Kabupaten Balangan}

Hipotesis ketiga dalam penelitian ini diujikan untuk mengetahui variabel yang dominan yang mana hasil dari pengujian tersebut diketahui bahwa untuk variabel pola pikir (mindset) terbukti berpengaruh signifikan yang dominan terhadap kinerja ASN Pada Kantor Kecamatan Batu Mandi Kabupaten Balangan, untuk itu hendaknya pihak instansi dapat lebih memperhatikan dan meningkatkan kembali akan aspek pola pikir pegawai ini karena dengan pola pikir yang baik dalam bekerja, maka akan dapat membantu peningkatan kinerja pegawai menjadi lebih baik pula. Pola Pikir yang berkembang merupakan mindset yang positif, yang akan menghasilkan kemampuan yang terus berkembang. Dalam hal ini seperti komputer, mindset positif dapat di install sedangkan mindset negatif dapat di delete atau dihapus. Proses ini dapat dilakukan melalui terapi yang dapat diajarkan kepada siapapun melalui.

\section{PENUTUP}

\subsection{Kesimpulan}

1. Pengujian hipotesis pertama diketahui bahwa pola pikir (mindset), penilaian kerja dan pola kepemimpinan secara parsial terhadap kinerja ASN Pada Kantor Kecamatan Batu Mandi Kabupaten Balangan.
2. Pengujian hipotesis kedua diketahui pula bahwa variabel pola pikir (mindset), penilaian kerja dan pola kepemimpinan secara simultan terhadap kinerja ASN Pada Kantor Kecamatan Batu Mandi Kabupaten Balangan.

3. Pada pengujian hipotesis ketiga diketahui variabel pola pikir (mindset) yang berpengaruh dominan terhadap kinerja ASN Pada Kantor Kecamatan Batu Mandi Kabupaten Balangan

\subsection{Saran}

1. Pihak instansi perlu lebih memperbaiki pola pikir pegawai dengan menanamkan pada pegawai baik dalam diklat maupun dalam praktek kerja setiap hari, dengan cara menanamkan kepada pegawai bahwa bekerja sebagai ibadah, menghindari sikap tidak terpuji, bekerja harus dilakukan secara profesional, meningkatkan kompetensi diri secara terus menerus, pelayan dan pengayom bagi masyarakat, pegawai untuk selalu bekerja sesuai dengan peraturan yang berlaku dan mengembangkan pola pikir pegawai selalu terbuka dan selalu bersikap realistis dalam bekerja.

2. Hendaknya pihak instansi dapat lebih meningkatkan kembali akan variabel penilaian kerja terhadap pegawai unsur yang dapat dinilai dalam penilaian pelaksanaan kerja pegawai adalah kesetiaan, prestasi keja, tanggungjawab, ketaatan, kejujuran, kerjasama, prakarsa dan kepemimpinan. Penilaian dilakukan oleh pejabat penilai seperti atasan langsung yang bisa dilakukan dengan waktu yang ditentukan seperti perbulan, persemester maupun pertahun.

3. Untuk itu pimpinan kecamatan perlu meningkatkan kembali akan perananya sebagai pimpinan dalam menentukan tujuan pelaksanaan kerja yang realistis, melengkapi bawahannya dengan sumber dana guna menjalankan tugasnya, menciptakan komunikasi yang baik, memberikan hadiah yang sepadan untuk mendorong prestasi 
pegawai, dapat mendelegasikan wewenang pegawai, dapat menghilangkan hambatan-hambatan terhadap pelaksanaan pekerjaan dan selalu menunjukkan perhatian para pegawainya dalam lingkup pekerjaan.

4. Guna meningkatkan kinerja pegawai melalui pengembangan pola pikir, aspek penilaian maupun pola kepemimpinan, maka hendaknya pihak Kantor Kecamatan Batu Mandi Kabupaten Balangan harus lebih konsisten dan perlu mempunyai komitmen kuat dalam membuat program kerja tersebut, agar tujuan organisasi dapat dicapai.

\section{DAFTAR PUSTAKA}

Andi Hakim, 2011, Dahsyatnya Pikiran Bawah Sadar, Rajawali Press, Jakarta

Arikunto Suharsimi, 1992, Prosedur Penelitian Suatu Pendekatan dan Praktek, Rineka Cipta, Jakarta

Bambang Guritno dan Waridin, 2005, Manajemen Sumber Daya Manusia, Bumi Aksara, Jakarta

Budiman, 2011, Pola Pikir (Mindset), Nova Media, Surabaya

Budiono, 2010, Manajemen Prestasi, Budi Mulia, Bandung

Carol S Dweck, 2006, Mindset (the psikologi of Success), Gramedia Indonesi, Jakarta

Carol S Dweck, 2012, Summary Mindset, Gramedia Indonesi, Jakarta

Dessler, Gary, 1997. Manajemen Sumber Daya Manusia. Jilid I. Jakarta: Prenhallindo.

Dessler, 2000, Management of Quality, PT, Rajawlai Press, Jakarta

Dessler, Gary, 2007. Manajemen Sumber Daya Manusia. Jilid IV. Jakarta: Prenhallindo.

Efendi, 2002, Manajemen Organisasi, Alumni, Bandung

Gomes Faustino.C., 1995, Manajemen dan Perilaku Sumber Daya Organisasi, Andi, Yogyakarta
Ghozali. Imam, 2006, Metode Penelitian dan Aplikasi Stasistik, Buana Karya, Jakarta

Gomes Faustino.C., 2000, Manajemen Sumber Daya Manusia, Andi, Yogyakarta

Greenberg, 1999, Human Relation dan Public Relation dalam Manajemen, Bandung : Alumni

Gunawan, 2007, Psikologi Organisasi, Rineka Cipta, Jakarta

Harotno, 2010, Pola Pikir Dalam Bekerja, Salemba, Jakarta

Hasibuan, 2000, Ilmu Manajemen, BPFE, Yogyakarta

Handoko.T.Hani, 2010, Manajemen Personalia dan Sumber Daya Manusia, Edisi Revisi, Penerbit BPFE, Yogyakarta

Husnan Suad dan Heidjrahman, 1990, Manjemen personalia, (MP) Edisi ke empat, Penerbit BPFE Yogyakarta

Hanafi, 2001, Manajemen Perusahaan, Roda Mas, Surabaya

Husnan Suad dan Heidjrahman, 1999, Manjemen personalia, (MP) Edisi ke enam, Penerbit BPFE Yogyakarta

Hartoyo, 1997, Manajemen, Rineka Cipta, Jakarta

Khodijah, 2006, Pola Pikir dan Motivasi Psikologi, Balai Pustaka, Jakarta

Khairunnisa, 2013, Analisis Pengaruh Kepemimpinan, Pola Pikir dan Penilaian Kerja Terhadap Kinerja Pegawai Pada Dinas Koperasi Kota Banjarmasin, FE Unlam, Banjarmasin

Lukman, 2009, Pola Pikir Elemen Sumber Daya Organisasi, Pradya Paramita, Jakarta

Mangkunegara. A.A. Anwar Prabu. 2005. Manajemen Sumber Daya Manusia Perusahaan. Penerbit PT. Remaja Rosdakarya. Bandung

Mulyanto, 2003, Kepemimpinan, Rineka Cipta, Jakarta

Mulyadi, 2007, Kekuatan Pola Pikir, Gramedia Indonesia, Jakarta

Muhammad Ridwan, 2012, Pengaruh Pola Pikir (Mindset), Penilaian Kerja dan Pola Kepemimpinan 


\section{Terhadap Kinerja ASN Pada Kantor Kecamatan Banjarmasin Barat, Unlam Banjarmasin}

Nurulhuda, 2010, Pengaruh Disiplin Kerja, PEnilaian, dan Kepemimpinan terhadap Kinerja Pegawai Pada Kantor Pemko Banjarmasin Bidang Pemerintahan, Unlam Banjarmasin

Notoatmodjo dan Soekidjo, 2002, Kualitas dan Kuantitas Kerja, Balai Pustaka, Jakarta

Pratisto, Arif, 2004, Cara Mudah Mengatasi Statistik dan Rancangan Percobaan dengan SPSS 12, PT Elex Media Komputindo Kelompok Gramedia, Jakarta

Prawirisentono, 1999, Manajemen Produktivitas, Buana Press, Bandung

Peraturan Menteri Pendayagunaan Aparatur Negara Nomor: PER/09/ M.PAN/5/2007 tentang Pedoman Umum Penetapan Indikator Kinerja Utama di Lingkungan Instansi Pemerintah, Jakarta

Pamudji, 1999, Kepemimpinan, Rineka Cipta, Jakarta

Rivai. Vincent, 2002, Manajemen Operasional Perusahaan, Multi Media Jaya, Surabaya

Swietenia Rita, 2009, Manajemen Produktivitas, Rineka Cipta, Jakarta

Setyono. A, 2006, Perilaku Keorganisasian, Pustaka Sinar Harapan, Jakarta

Suhardjito, 1999, Manajemen Perusahaan, Rineka Cipta, Jakarta

Solimun, 2004, Metodologi dan Komputer Statistik, Rineka Cipta, Jakarta

Sugiono, 1999, Stasistik Untuk Penelitian, CV. Alfabeta, Bandung

Sekaran, Uma, 2003, Reseach Method For Business (Skill Building, Approach),
Third Edition, John Weiley and Sans Inc, America

Suparno, 2002, Metode Penelitian dan Statsitik, UNNES Press, Semarang

Simamora. Hendry, 2002, Manajemen Sumber Daya Manusia, Penerbit STIE YKPN, Jakarta

2004, Manajemen Sumber Daya Manusia, Buku II, Penerbit STIE YKPN, Jakarta

Singarimbun \& Efendi, 1995, Metode Penelitian, PT. Rajawali Press, Jakarta

Sri. Purwanti, 1997, Ilmu Manajemen, Rineka Cipta, Jakarta

Siagian F. Sondakh, 1990, Manajemen dan Kepegawaian, Alfabeta, Bandung

Wibowo 2007, Manajemen Pengelolaan $S D M$, Pusaka Tjaya, Surabaya Winardi, 1999, Penghantar Ilmu Manajemen, Nova, Bandung Yoga, 2008, Menantang Cara Berpikir Anda, Mendali Pratama, Jakarta 